\title{
An assessment of the effect of noise pollution on rental values of properties in Nigeria
}

\begin{abstract}
The study assessed the impact of noise pollution on rental values of properties in Nigeria. The study adopted a survey research design. Questionnaire was designed to obtain data from the respondents. The close ended questions were used to collect the data. The questionnaire was distributed to respondents through their emails and phone numbers in May, 2020 during the Covid-19 lockdown. The study adopted purposive and convenient sampling technique. The data analysis was based on sixty one questionnaires retrieved. The data were analyzed with descriptive statistics such as frequency, percentage and mean. The results revealed that noise pollution reduces property rental values with a mean of 2.7 which is greater than the mean rating of 2.5. The study concludes that noise pollution negatively impacts property values. The study recommends the development and enforcement of noise

abatement measures to improve urban neighbourhood quality and increase property values.
\end{abstract}

Volume 5 Issue 5 - 2020

\begin{abstract}
Ebiwari Wokekoro
Department of Estate Management, Rivers State University, Nigeria
\end{abstract}

Correspondence: Ebiwari Wokekoro, Department of Estate Management, Rivers State University, Port Harcourt, Nigeria, Tel +2348035486590,Email ebi_wokekoro@yahoo.com

Received: July 18, 2020 | Published: September 14, 2020

Keywords: Noise Pollution, Rental Value, Properties, Nigeria

\section{Introduction}

Noise pollution is an unwanted, undesirable, excessive and irritating sound that has a deleterious effect on humans, plants, animals, properties, the built and the natural environment. ZambranoMonserrate and Ruano ${ }^{1}$ defined environmental noise as an unwanted sound which could be generated by anthropogenic activities including industrial or commercial activities, engine vehicles and melodies at high volume. Zambrano-Monserrate and Ruano ${ }^{1}$ stated that noise that exceeds the ambient sound level by more than 10 decibels $(\mathrm{dB})$ as measured from 15 feet from the source as measured from inside any property or on a public street is prohibited.

Shield ${ }^{2}$ stated that noise impacts property value due to a variety of factors that prospective buyers of residential properties may consider such as sleeping difficulty, stress and potential cardiovascular risks. Shield ${ }^{2}$ further stated that "properties that are in close proximity to noise sources, such as airports, railway lines and busy streets, tend to be lower in the market." According to Shield "Noise can affect property value for commercial buildings as well. When companies look to buy new properties, they will likely consider how excessive outdoor noise might negatively impact the stress and productivity of their employees." Shield ${ }^{2}$ also opined that commercial and residential property owners frequently monitor the value of their properties and that one of the most overlooked factors when considering the factors that can increase or decrease real estate value is noise pollution. Shield ${ }^{2}$ also averred that excessive noise on or near the property can significantly reduce its value.

The effects of noise pollution on property values have been widely studied in developed countries but there are few studies in developing countries particularly in Nigeria. It is against this background that this study was undertaken to assess the impact of noise pollution on property values.

\section{Literature review}

Zambrano-Monserrate and Ruano ${ }^{1}$ examined the effects of environmental noise on housing rental values in Machala, Ecaudor and found that environmental noise reduces rental values by $1.97 \%$ for one decibel increase. Their study further revealed that the total economic value produced by noise pollution in Machala (Ecuador) was estimated at US $\$ 66,453.20$ per month. Their study concluded that environmental noise is a negative externality that affects the housing rental market in Machala (Ecuador).

Espey $^{3}$ examined the effects of airport noise on residential property values Reno-Sparks area using hedonic price method and revealed that there is a statistically significant negative relationship between airport noise and residential property values, with the average home in areas where noise levels are 65 decibels or high selling for about $\$ 2400$ less than equivalent homes in quieter areas.

Ozdenerol, Huang, Javadnejad and Antipova ${ }^{4}$ examined the impact of traffic noise on housing value in Shelby County, Tennessee and found that traffic noise significantly impacts housing values negatively. Their study further revealed that discount on housing values increases as the noise levels increases. Their study also indicated that the increased intensity of traffic volume within the Memphis Aerotropolis boundary leads to a further decrease in housing values.

Walker $^{5}$ examined the impact of railroad noise pollution on commercial and residential property values in Memphis, Tennessee using a unique cross sectional dataset of property values with manually collected noise measurements using hedonic regression and found that residential property reduced by 13 percent located within the 65 decibel contour from the railroad noise origin. The study further revealed that neither proximity to rail nor noise level significantly affect commercial property values. The study recommends that "exact measures of noise levels and utilizing GIS versus simple proximity may be a better approach for estimating impacts."

Suksmith and Nitivattananon ${ }^{6}$ examined the relationship between aviation impacts and property values in the case of Suvarnabhumi Airport in Thailand for application to the possible improvement of compensation packages. Their study adopted multiple regression analysis to determine the relationship between impacts of aviation safety, noise, scenery, air pollution, and traffic and property value changes. They used data from a survey sample of communities around the airport. Their study found only noise and air pollution demonstrate 
significant negative relations with property value for both the overall neighborhood and for separate land used types, The study further revealed that The effect of noise had a higher impact on property price than the effect of air pollution.

El-Gohary ${ }^{7}$ investigated property valuation model effect of traffic noise on property value and found that there is a negative relationship between the noise level emitted from the nearby freeway and the market value of a property.

Duarte and Tamez ${ }^{8}$ investigated the impact of noise pollution on residential property value and found that noise decreases residents' well-being, and property values.

Wilhelmsson ${ }^{9}$ examined the impact of traffic noise on the values of Single-family houses by adopting the hedonic price method and found that noise pollution had substantial negative effect on housing values. The study further revealed that the value of a single-family house is discounted by $30 \%$ if located near a road with loud noise.

Sklarz and Miller ${ }^{10}$ examined the impact of noise on residential property values in San diego and found that noise is a very significant factor influencing the values of any given site and property value.

Lin, I- $\mathrm{H}^{11}$ assessed the effect of parks on surrounding property values using hedonic models and multilevel models and found that parks primarily for passive recreation and active recreation have a positive impact on nearby property values and disturbance and a negative impact on adjacent property values respectively, but significantly different impacts are associated with different park facilities.

Neumann ${ }^{12}$ assessed how noise pollution affect property values and found that noise pollution reduces home value and affect a person's sanity. Neuman ${ }^{12}$ also found that quieter areas are generally deemed more desirable, and real estate prices tend to reflect that. The study "further stated that "the presence of an airport could cause properties in close proximity to sell up to $20 \%$ lower than the average of homes in the next concentric circle. Neumann ${ }^{12}$ also stated that "sellers of homes within a 2 -mile radius of an airport will discount prices $13.2 \%$ from the going rate of other homes in the same ZIP code; sellers will also offer discounts for close proximity to railway tracks $(12.3 \%)$ and highways (11.3\%)."

Shield ${ }^{2}$ examined the effect of noise pollution on property value and found that excessive noise either in or near residential and commercial properties reduce their values.

$\mathrm{PK}^{13}$ investigated how much noise affect real estate prices using a noise versus real estate price calculator and found that a $1 \mathrm{Ldn}$ increase in noise level, decreases property value by $4 \%$.

It is very difficult to have a complete knowledge of the neighbourhood characteristics before you buy a home - especially in terms of noise. Recent research revealed a noisy environment can be a liability to a property worth. Noise pollution is anything which interferes with, disrupts or diminishes one's quality of life. Noise pollution can drastically affect property value. ${ }^{14}$

Pan ${ }^{15}$ examined noise factors that affect home values and found that airport within two miles radius reduce property values by $13.2 \%$, rail track by $12.3 \%$, Highways by $11.3 \%$, 24-hour supermarket discount nearby properties for $5.1 \%$, homes within 0.1 mile of a school are discounted $4.3 \%$, but if within 1 mile to 5 miles, families will pay an $8.6 \%$ premium for the convenience, a nearby fire station reduce home values by $1.8 \%$ and a food store in general increases home prices by $3.4 \%$.

Toothman (nd $)^{16}$ stated that there are ten things in a neighbourhood that can devalue a house, namely: noise from airport, train tracks, nearby highway, athletic complex, power plants, landfills, cell phone tower, strip club and criminal activity.

Feitelson, Hurd and Mudge ${ }^{17}$ examined the impact of airport noise on willingness to pay for residences and found that beyond a certain noise disturbance threshold, households are not willing to pay anything for the residence; yet, different households have different thresholds.

Nikolaos, Dimitra and Agapi ${ }^{18}$ revealed that properties in close proximity to highways have $8-10 \%$ reduction in value than those in a quiet area, real estates close or next to railways is $6.7 \%$ decrease in market value and an increase in the noise of 1 decibel $(\mathrm{db})$ decreases the value up to $0.3 \%$ of suburban properties close to airports.

Lightbearer ${ }^{19}$ examined the impact of noise pollution on the residential property values in Enugu metropolis and found that people prefer a serene environment to a noisy one, government and the public do not participate in urban noise pollution control, noise impacts on property rent and people are not aware of the prolonged impact of noise on health.

Jariwala, Syed, Pandya and Gajera ${ }^{20}$ stated that noise pollution can impair one's enjoyment of property, leisure time, increases antisocial behaviour, degrades residential, social, learning environments and resulting in economic losses.

Department for Environment, Food \& Rural Affairs ${ }^{21}$ stated that noise affect health, wellbeing, productivity and the natural environment and that noise impacts can be incorporated into a cost benefit analysis.

Ganiyu and Adedeji22 investigated major sources of noise pollution and its impact on the built environment of Oba - Ile housing estate in Akure, Ondo State, Nigeria and found that noise pollution impacts residents and the built environment negatively. Their study recommends good design and building orientation, adequate set back and reduction of noise from sources as some of the ways to minimize the problems of noise pollution in built environment.

Perfect Pollucon Services (nd) ${ }^{23}$ stated that Noise Impact Assessment (NIA) is part of Environmental Impact Assessment (EIA) and NIA is to measure current noise quality assessment of a study area, assess impacts of new projects on local noise, its impact and acceptability.

According to Parris K and McCauley R (nd) ${ }^{24}$ "Some of the ways noise pollution from traffic can be reduced are by developing quieter roads and cars; installing noise-reduction barriers around major traffic areas; lowering speed limits; educating drivers; and implementing relevant legislation to progressively reduce noise. Other strategies include the use of better materials; improved site planning; and the undertaking of detailed environmental assessments before construction of houses and industrial sites is permitted, with followup assessments after construction is completed."

Bateman, Day and Lake ${ }^{25}$ conducted a study on the valuation of transported-related noise in eight submarkets in Birmingham and found that road traffic noise, rail noise and airport noise negatively impacted on property prices. 


\section{Research methods}

The study was conducted in Nigeria, popularly known as the giant of Africa. The study adopted survey research design. The study adopted the purposive and convenient sampling technique. Questionnaire was utilised to collect data from the Estate Surveyors and Valuers and the literate population in urban areas in Port Harcourt. The questionnaire was designed with google forms and distributed to respondents in May, 2020 during the COVID-19 lockdown through their emails and WhatsApp mobile phone numbers. The respondents are residents of Lagos, Abuja, Port Harcourt and Yenegoa. The study used closed ended question to assess the impact of noise pollution on rental values. A four point rating system was adopted as follows: no impact (1 point), Low impact (2), medium impact (3) and high impact (4). Sixty one questionnaires were retrieved and the analysis was based on 61 valid responses. The responses are No impact $(2=3.3 \%)$, Low impact $(17=27.9 \%)$, Medium $(24=39.3 \%)$ and high impact $(18=29.5 \%)$. The cut off mean impact was computed as $1+2+3+4 / 4=2.5$. The decision rule is that If the mean impact is less than 2.5 the impact is low and if the mean impact is equal to or greater than () 2.5 the impact is high.

$$
\text { Cut }- \text { off mean }=\frac{4+3+2+1}{4}=\frac{10}{4}=2.50
$$

\section{Results and discussion}

Sixty one questionnaires were retrieved and the analysis was based on 61 valid responses. The responses in Table 1 are No impact $(2=3.3 \%)$, Low impact $(17=27.9 \%)$, Medium $(24=39.3 \%)$ and high impact $(18=29.5 \%)$. The computed weighted mean $(2.7)$ which is greater than the cut-off mean of 2.5 which indicates that noise pollution has a high impact on rental values. In other words, noise pollution has a high negative impact on rental values. The frequencies also indicated that $96.7 \%$ of the respondents agreed that noise pollution has negative impact on rental values (low impact with $27.9 \%$, medium impact with $39.3 \%$ and high impact with $29.5 \%$ ). The study shows that noise pollution decreases rental values. The results of this study are consistent with results of previous studies that noise pollution

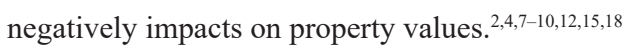

Table I Impact of noise pollution on rent

\begin{tabular}{|c|c|c|c|c|c|}
\hline Impact of noise pollution on rent & Weight & Frequency (N) & Percentage (\%) & Total weight & Weighted mean \\
\hline No Impact & I & 2 & 3.3 & 2 & $|64 / 6|=2.7$ \\
\hline Low Impact & 2 & 17 & 27.9 & 34 & \\
\hline Medium Impact & 3 & 24 & 39.3 & 72 & \\
\hline High Impact & 4 & 18 & 29.5 & 56 & \\
\hline Total & 10 & 61 & 100 & 164 & \\
\hline
\end{tabular}

\section{Conclusion}

The study was conducted to assess the impact of noise pollution on rental values in Nigeria. The study revealed that noise pollution reduces property rental values. The study concludes that noise pollution negatively impact property values. The study recommends that development and enforcement of noise abatement measures will improve quality of urban neighbourhoods and increase property rental values.

\section{Acknowledgments}

None.

\section{Funding}

None.

\section{Conflicts of interest}

The authors declare there are no conflicts of interest.

\section{References}

1. Zambrano-Monserrate MA, Ruano MA. Does environmental noise affect housing rental prices in developing countries? Evidence from Ecuador. Land Use Policy. 2019.

2. Shield S. Does noise pollution affect your property value? 2017.

3. Espey M. The effects of airport noise on residential property values. Growth and Change. 2000;31(3):408-419.
4. Ozdenerol E, Huang Y, Javadnejad F, et al. The impact of traffic noise on housing values. Journal of Real Estate Practice and Education. 2015;18(1):35-53.

5. Walker JK. Silence is golden: railroad noise pollution and property values. 2016. 27 p.

6. Suksmith PL, Nitivattananon V. Aviation Impacts on property values and management: the case of suvarnabhumi international airport. International Association of Traffic and Safety Sciences (IATSS) Research. 2015;39:58-71.

7. El-Gohary M. Property valuation model effect of traffic noise on property value ECE 557 PROJECT. 2004.

8. Duarte MC, Tamez GC. Does noise have a stationary impact on residential values? Journal of European Real Estate Research. 2009;2(3):259-279.

9. Wilhelmsson M. The impact of traffic noise on the values of singlefamily houses. Journal of Environmental Planning and Management. 2000;43(6):799-815.

10. Sklarz M, Miller N. The impact of noise on residential property value in San diego. Collateral Analytics Research. 2018:1-9.

11. Lin I-H. Assessing the effect of parks on surrounding property values using hedonic models and multilevel models. A dissertation submitted in partial fulfillment of the requirements for the degree of doctor of philosophy in geography at The University of Wisconsin-Milwaukee. Theses and Dissertations. 2016.

12. Neumann KD. What is noise pollution and how does it affect property values? 2018.

13. PK. How much does noise affect real estate prices? 2019. 
14. Noise pollution can drastically affect property value.

15. Pan Y. Decibel hell: the ear-splitting things that will disturb your home's value. 2017

16. Toothman J. Top 10 things that devalue your house.

17. Feitelson EI, Hurd RE, Mudge RR. The impact of airport noise on willingness to pay for residences. Transpn Res. 1996;I(I):1-14.

18. Nikolaos K, Dimitra V, Agapi X. Real estate values and environment: a case study on the effect of the environment on residential real estate values. International Journal of Academic Research Part III. 2011;3(1):861-868.

19. Lightbearer. The impact of noise pollution on the residential property values in Enugu metropolis of Enugu state. 2019.

20. Jariwala HJ, Syed HS, Pandya MJ, et al. Noise pollution \& human health: a review. 2017.
21. Department for Environment, Food \& Rural Affairs.Guidance Noise pollution: economicanalysis. 2013

22. Ganiyu SA, Adedeji YMD. A study of the sources of noise pollution and their impacts on the built environment (A case study of Oba-Ile Housing Estate, Akure, Nigeria). West Africa Built Environment Research (WABER, 2011). Accra, Ghana Conference; 2011.

23. Perfect Pollucon Services (nd). Noise impact assessment.

24. Parris K, McCauley R. Noise pollution and the environment. Earth and environment. Australian academy of science.

25. Bateman II, Day BH, Lake I. The valuation of transport-related noise in Birmingham. Non-Technical Report to the DfT, Centre for Social and Economic Research on the Global Environment \& Centre for Environmental Risk, School of Environmental Sciences, UK: University of East Anglia; 2004. 